\title{
移動体におけるDGPSとGPS/GLONASS単独測位
}

\section{Onboard Positioning by GLONASS and GPS with and without Differential}

浪江 宏宗*・安田 明生**

\author{
Hiromune NAMIE and Akio YASUDA
}

\begin{abstract}
GLONASS, being operated by Russian Space Agency, is a world wide satellite navigation system similar to GPS of US. Although the satellite number of the system has been reduced to 15 from the FOC of 24 satellites, as the SA of GPS is not introduced, the positioning accuracy is better than that of GPS during the period of a small DOP value. The use of both GPS and GLONASS together increases the number of usable satellites and improves the accuracy and availability especially while driving in the urban canyon. The authors tried the GLONASS and GPS+ GLONASS positioning while driving car and navigating ship. The accuracy is evaluated against the DGPS with MF marine radio beacon correction data dissemination. It is confirmed that the higher accuracy is available in the positioning by GLONASS with small DOP value and GPS+ GLONASS with more than 3 GLONASS satellites than that by GPS alone.
\end{abstract}

\section{1.はじめに}

GLONASS (Global Navigation Satellite System)は旧ソ連によって開発され、ロシア共和国により運 用されているGPSと同様の衛星測位システムである。1999年 5 月現在運用されているGLONASS衛星は、 完成時の 24 機から減少し15機である。しかし、GPSにおけるSAのような故意の測位精度劣化操作が行われ ていないので、高精度な擬似距離測距が案時間で可能であり、GLONASS単独測位でGPS単独測位よりも 高精度な実時間測位が期待できる。

このような状況において、筆者等はこれまでにほとんど報告のないGLONASSの移動体での測位状況を 把握するために、自動車及び船舶の移動体で測位を行った。移動体で測位を行う場合、定点測位々異なり 自動車ではビル等の建築物による衛星の遮蔽やマルチパスによる測位への影響の変化、船舶では主に進路 変更に伴って発生する船上構造物 (レーダ・マスト、ブリッジ等)による衛星の遮蔽、ローリング、ピッチ ングによって発生する、低仰角衛星からの電波の、海面によるマルチパスの測位への影響の周期的な变化 等が予想される。これらは定点測位のみではその挙動を把握することは困難であり、実際に移動体で測位 を行い評価する必要がある。

\section{GLONASSの概要}

図 1 にGLONASS衛星の配置概念図を示す。GPSが軌道傾斜角約55度の 6 軌道に 4 衛星ずつ配置される のに対して、GLONASSは軌道傾斜角64.8度の 3 軌道に 8 衛星ずつ配置され、合計 24 衛星で運用される。 しかし、1995年に一旦24衛星による運用が開始された後打ち上げが行われず、次々と衛星がその寿命によ

\footnotetext{
* 学生会員 東京商船大学大学院（开135-8533 東京都江東区越中島2-1-6）

**正 会 員 東京商船大学（厂135-8533 東京都江東区越中島2-1-6)
} 
つて使用できなくなったため、昨年末むでに14 衛星による運用となっていた。1998年12月30日 に約 4 年振りに衛星の打ち上げがあり、3 衛星 が追加されたが、その後 2 衛星が寿命となり、 1999年 5 月現在 15 衛星での運用となっている。 GLONASSにはGPSにおけるSAのような故意 の精度劣化操作は行われていないので、当初の 計画通り24衛星が配置されれば、単独測位でも 現在のGPS単独測位SPS (Standard Positioning Service：標準測位サービス)よりも高精度 な擬似距離測距が実時間で可能になり、高精度 な実時間測位が期待できる。

\section{3. 基礎データ}

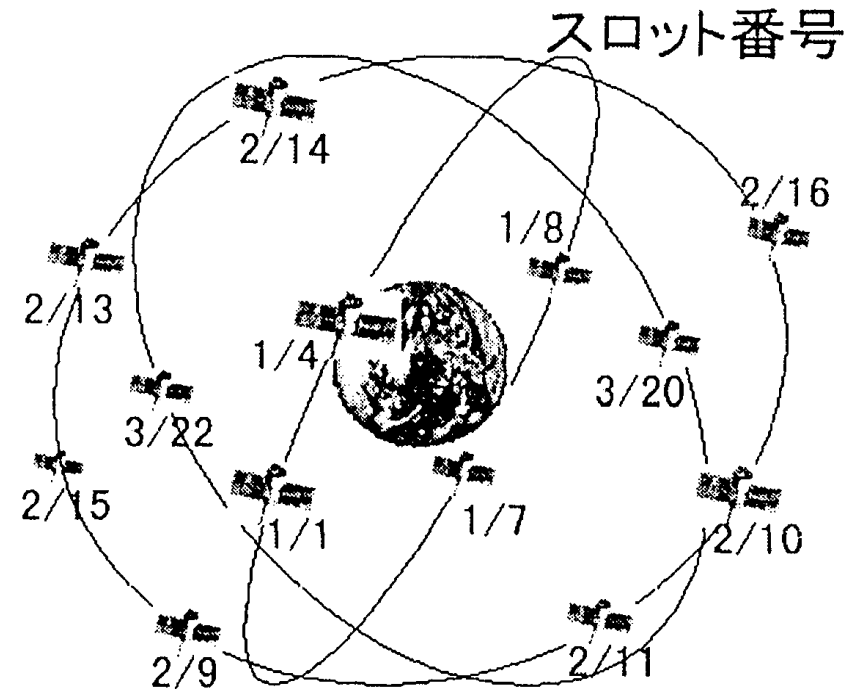

移動体上での測位に先立ち、基礎的なデータを収集す るために定点測位を行った。今回、測位に使用した受信 機注Ashtech社製GG-24一周波GPS/GLONASS受信 機、及びNovAtel Communication社製二周波3151R型 RT- 2 受信機で、GPS及びGPS/GLONASSのアンテナ は東京都江東区越中島の東京商船大学航海学科実習棟の 屋上の定点(北緯35度39.9884分, 東経139度47.5398分, 海拢高度 $21.89 \mathrm{~m}$ 、日本測地系) に、互いに約 $1 \mathrm{~m}$ 離して 設置した。

図 2 にGLONASS単独測位及びGPS+GLONASS単 独測位の約14時間にわたる毎秒の水平方向測位分布を示 す。GLONASS単独測位はHDOP値が 2 以下の場合の測 位結果も分けてプロットしている。図 3 には同じく高度 測位結果の時系列の一例をまとめて示す。見易くするた めGLONASSはWGS-84座標系における棈円体高、それ 以外海抜標高で示している。図 2，3より、GLONASS 単独測位では数十秒の間に測位值の䛊差が連続的に $100 \mathrm{~m}$ 以上にわたって増大する現象が見られる。

表 1 亿定点において測位に使用した衛星数の割合を示 す。カッコ内は測位回数 ( 1 秒に 1 回測位) である。同表 より、測位に使用しているGLONASS衛星の数は常に 6 機以下であり、上空が開けた定点でもGLONASSのみで は三次元測位に必要な 4 衛星に満たない割合が $23.2 \%$ と、全体の 4 分の 1 を占めていることが分かる。 GLONASS 単独測位の測位率は $68.2 \%$ にずず、 GLONASS衛星が15機しか運用されていないことによ る影響が現れている。また、三次元測位が行われていて

図 1 GLONASS衛星の配置概念図

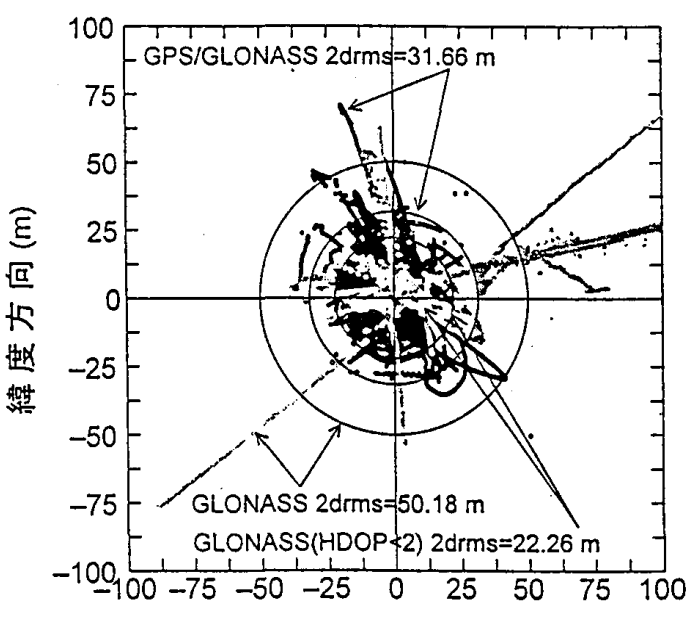

経度方向 $(m)$

図 2 定点GLONASS水平方向測位分布

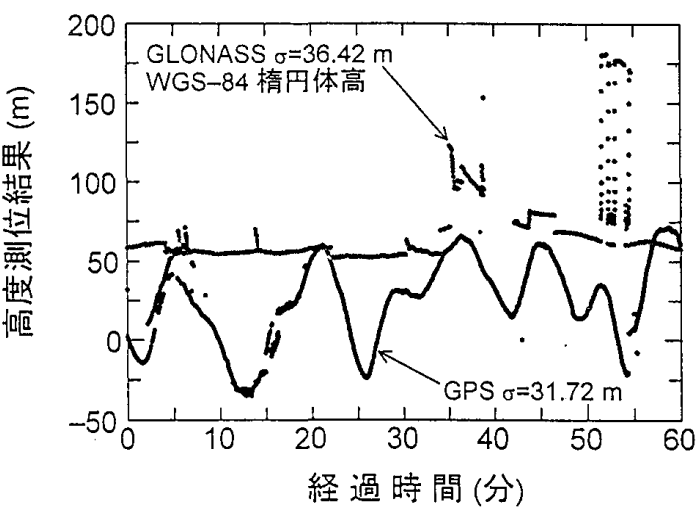

図 3 定点高度測位結果時系列一例 も、衛星数の減少により HDOP值が 5 及び10より大きく なった割合がそれぞれ $17.7 \%$ と.4\%あり、GPS単独測位と比較して誤差が大きいことが分かる。

さらに、表 2 にこのときの測位結果を示す。同表及び図 $2 ， 3$ から、GLONASS単独測位では数十秒間 にわたり測位值の誤差が連続的に $100 \mathrm{~m}$ 以上にまで増大することがあるため、測位精度はGPS単独測位と 同程度となっている。GPS＋GLONASS単独測位はGPS単独測位より精度が高いことが分かる。また、 
HDOP值が 2 よりさい場合 の GPS + GLONASS単独測位 ではさらに高精度である。

図 4 にGLONASS単独測位 の緯度方向測位結果と、そのと き測位に使用した衛星数及び HDOP值の時系列の一例を示 す。同図より、測位に使用して いる衛星数は常時 4 機であるに もかかわらず、その配置によっ てHDOP值は最大 40 近くにま で連続的に増大し、緯度方向測 位值もその時間帯に $40 \mathrm{~m}$ 以上ジ ヤンプしていることが分かる。 このDOP值の増大によって、 GLONASS単独測位の $100 \mathrm{~m}$ 以 上にのぼる連続的な测位精度の 劣化が発生している。また、こ の測位精度の劣化により、 GLONASS単独測位の $2 \mathrm{drms}$ は50.18m と、測位精度劣化操作がなされていないにもかかわらず、GPS単独測位と同程度の精度となって いる。以上のことから、現時点でGLONASS単独測位は24時間連続的には高精度測位が得られない状況で あるといえる。しかし、表 1 よりGPSと併用すれば常時測位に利用できる衛星数が 6 衛星以上となるため、 效果的であることが分かる。

次に、図 5 にGPS+GLONASS単独測位結果のうち、高度測位結果の時系列の一例を示す。同図より、

表 2 定点測位結果

\begin{tabular}{|c|c|c|c|c|}
\hline 目 & GPS & GLONASS & GLONASS(HDOP $\leqq 2)$ & GPS+GLONASS \\
\hline 測位時間 (1 秒毎) & 13.9 時間 & 13.9 時間 & 13.9 時間 & 16.7 時間 \\
\hline 測 位 率 & $100.0 \%$ & $68.2 \%$ & $19.3 \%$ & $100.0 \%$ \\
\hline $2 \mathrm{~d} \mathrm{r} \mathrm{m} \mathrm{s}$ & $49.42 \mathrm{~m}$ & $50.18 \mathrm{~m}$ & $22.26 \mathrm{~m}$ & $31.66 \mathrm{~m}$ \\
\hline 高度標淮偏差 & $31.72 \mathrm{~m}$ & $36.42 \mathrm{~m}$ & $16.05 \mathrm{~m}$ & $24.57 \mathrm{~m}$ \\
\hline
\end{tabular}

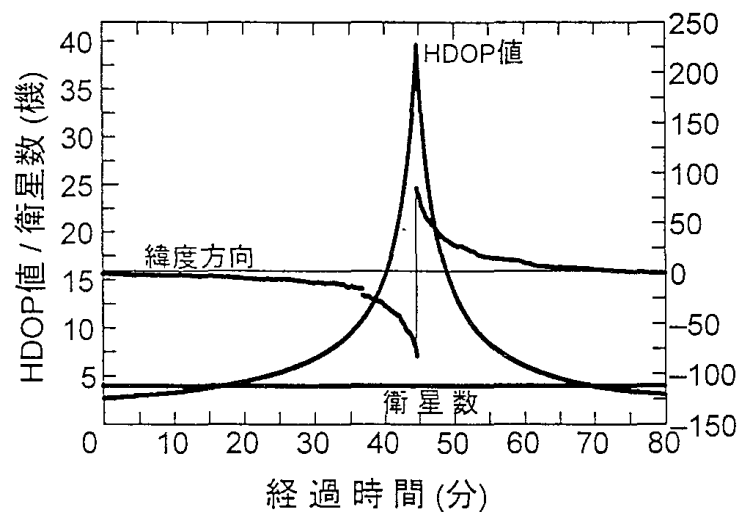

図 4 GLONASS測位緯度/衛星数/HDOP值の 時系列の一例

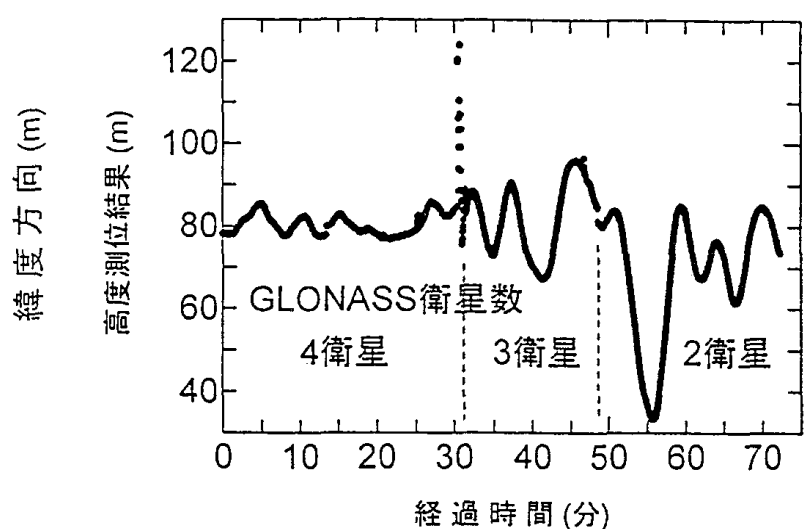

図 5 定点におけるGPS/GLONASS高度測位 結果の時系列の一例 
GPS +GLONASS単独測位では測位に使用するGLONASS衛星が 4 機以上、すなわちGLONASSのみで三 次元測位が可能である時間帯の測位精度は、GLONASS衛星の配置によるDOP值に依存し(ただし、GPS 単独測位の精度より劣化しない場合)、測位に使用しているGLONASS衛星が 3 機以下である時間帯の測 位状況は、GPSのSAに依存することが分かる。

\section{4．移動体における測位実験}

移動体における測位実験を自動車と船舶で行った。自動車では東京23区内を走行中に、また船舶では東 京商船大学の練習船汐路丸で、東京湾及び神津島までを航行中と錨泊中に測位を行った。定点測位と異な り、移動中の測位状況を把握するための比較対象をどのように決定するかが困難な問題となる。ここでは、 中波ビーコンDGPS ${ }^{(1)(2)(3)(4)(5)(6)(7)}$ の測位結果を真の值とし、同時刻の他のシステムの測位結果との差をと って評価することにした。

図 6 に前出の定点におけるGPS+GLONASS単独測位と同じ時間帯に測位を行った中波ビーコン DGPSの、水平方向測位分布の一例を示す。使用した受信機はTrimble Navigation社製 Ag-132受信機で、 中波ビーコン受信機と一体型のものである。また、表 3 にその測位結果をまとめて示す。中波ビーコン DGPSの測位率は $100 \%$ であった。また、 $2 \mathrm{drms}$ 及び高度測位結果の標準偏差は共に $1 \mathrm{~m}$ 以下であり、GPS/ GLONASS単独測位の測位精度評価に利用できると考 えられる。測位に使用した衛星数がGPS単独測位(表 1 参照)よりも少ないのは、GPS基準局 (神奈川県剱埼) と 利用者局間距離が約 $60 \mathrm{~km}$ 以上離れており、両局で同時に 受信できる衛星の組み合わせが異なったためである。

ここで、表 4 にこの定点測位において中波ビーコン DGPSの測位結果を真の值として、同時刻の他の測位結 果との差をとったものの標準偏差を示す。同表より、定 点測位で $2 \mathrm{drms}$ 及び高度測位結果の標準偏差が共に 1 $\mathrm{m}$ 以下であった中波ビーコンDGPSの測位結果を真の值 であると仮定しているが、必ず誤差を含んでいるので、 測位精度そのものを評価できているとは言えないが、お およその目安になると考光られる。よって、今回はこの 評価方法を使用することにした。

\section{1 自動車における測位実験}

写真 1 に今回の実験に使用した自動車の外観、写真 2

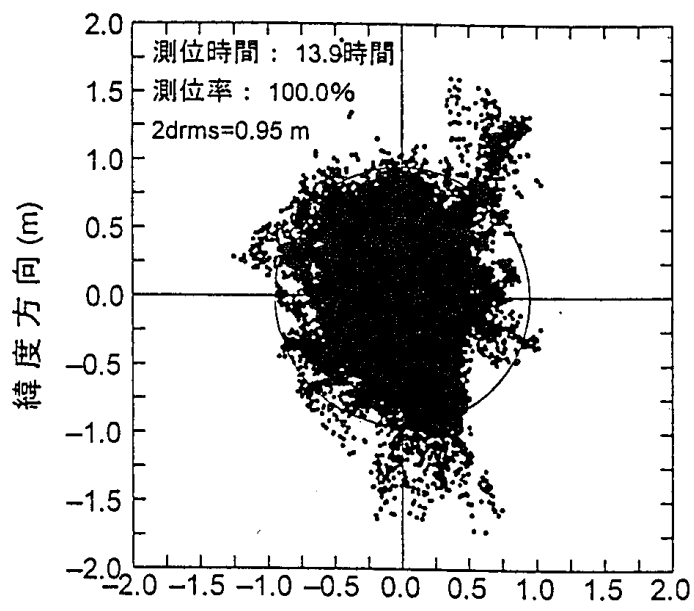

経度方向 $(\mathrm{m})$

図 6 定点における中波ビーコンDGPSの 水平方向測位分布の一例 に走行した銀座周辺の様子を車内から撮 影したものの一例を示す。また、図 7 に 今回行った自動車での都内走行実験の軌 跡を全て示す。今回の実験は東京商船大 学を出発して、皇居周辺、東宮御所周辺、 銀座周辺、上野方面、亀戸方面を走行し た。同図より、都内の市街地ばかりを走 行したことが分かる。写真 2 に示すよう に道路の両脇に上空を覆らようにビルが 林立する市街地や、一方通行の道路等比 較的狭い道路を中心に走行したため、受 信衛星数が 4 機以下となり三次元測位が できなくなる状況が頻繁に発生した。す なわち、衛星の受信状況が劣悪な状況で 今回の実験を行ったことになる。
表 3 定点における中波ビーコンDGPSの測位結果

\begin{tabular}{|l|c||c|rr|}
\hline 項 目 & 測位結果 & 使用衛星数 & 割 合 & (測位回数) \\
\hline \hline 測位時閒 $(1$ 秒毎) & 13.9 時間 & 5 衛星 & $1.9 \%$ & $(964)$ \\
\hline 測 位 率 & $100.0 \%$ & 6 衛星 & $30.3 \%$ & $(15,174)$ \\
\hline $2 \mathrm{~d} \mathrm{~m} \mathrm{~s}$ & $0.95 \mathrm{~m}$ & 7 衛星 & $45.5 \%$ & $(22,754)$ \\
\hline 高度標淮偏差 & $0.68 \mathrm{~m}$ & 8 衛星 & $22.2 \%$ & $(11,114)$ \\
\hline
\end{tabular}

表 4 定点測位結果の差(中波ビーコンDGPS基準)

\begin{tabular}{|c|c|c|c|}
\hline 項 目 & GPS & GLONASS & GLONASS(HDOP $\leqq 2)$ \\
\hline 測 位回数 & 49,421 & 34,164 & 9,657 \\
\hline $2 \mathrm{~d} r \mathrm{~m} \mathrm{~s}$ & $52.47 \mathrm{~m}$ & $57.36 \mathrm{~m}$ & $20.75 \mathrm{~m}$ \\
\hline 高度方向標準偏差 & $31.76 \mathrm{~m}$ & $36.87 \mathrm{~m}$ & $13.40 \mathrm{~m}$ \\
\hline
\end{tabular}




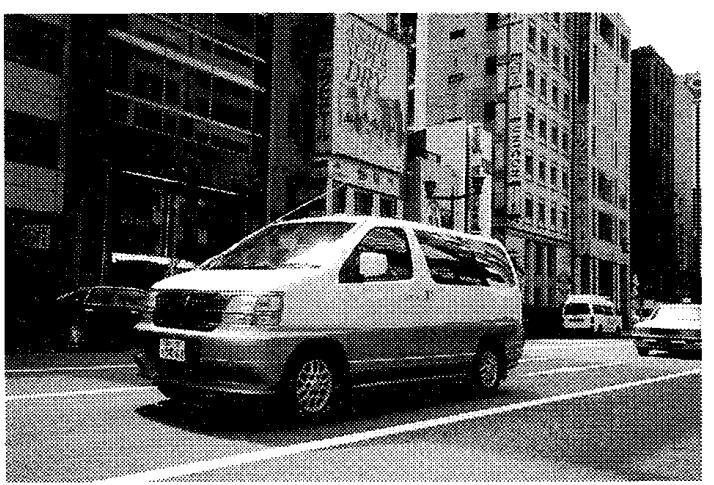

写真 1 自動車の外観

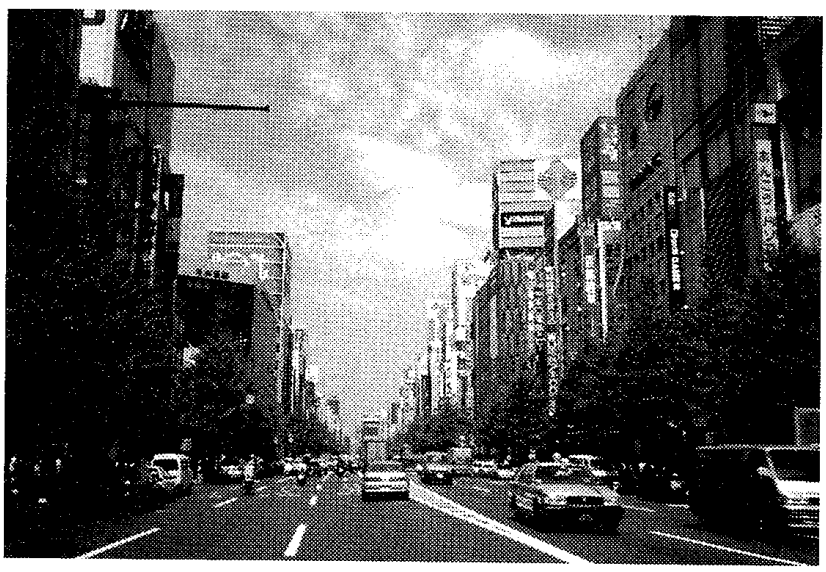

写真 2 銀座周辺の状況の一例

図 8 に常時GLONASS衛星 4 機以上で測位しながら皇居前広場 を 3 周したときの測位結果を示 す。それぞれ「・」はGPS単独測 位、「○」はGLONASS単独測位、 「口」は中波ビーコンDGPS測位の 結果を示して抢り、3 秒每に測位 結果をプロットしている。同図よ り、GPS単独測位はSAの影響に より自動車の進行方向に対して左 右にずれを生じており、同じ車線 を走行した 3 回の周回軌跡は全て

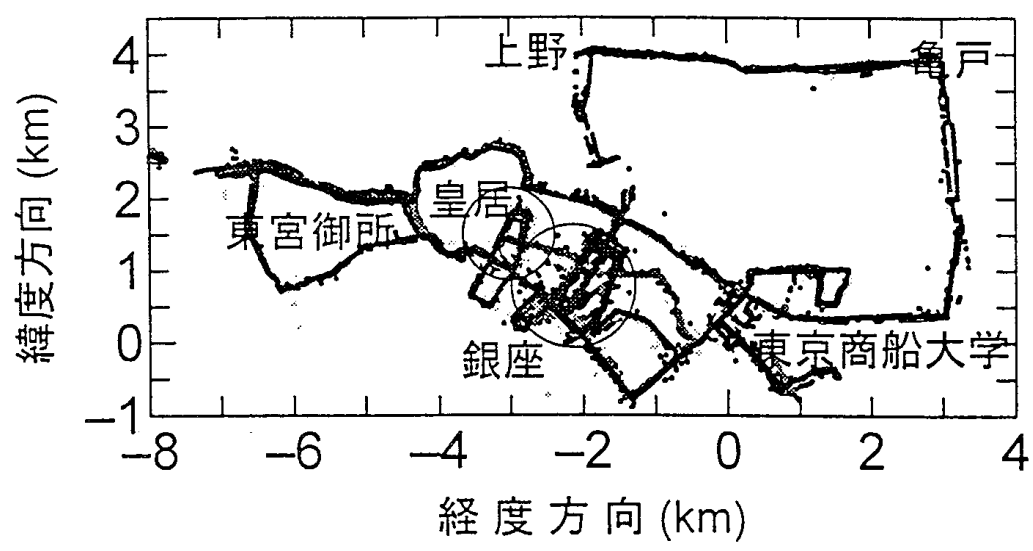

図 7 自動車におうる東京都内測位結果(全走行軌跡) 数十メートルずれていることが分 かる。GLONASS単独測位は衛星電波の遮断が発生し、DOP值が急激に増大した場合、定点測位で見られ たと同様に $100 \mathrm{~m}$ 程度の測位值のジャンプが見られる。しかし、GLONASS単独測位と中波ビーコンDGPS 測位による周回軌跡は、GPS単独測位の結果と比較してより良く重なり合っていることが分かる。

図 9 にこれらの測位結果と同時刻の中波ビーコンDGPS測位結果の差をとったものの水平方向分布を示 す。上空の開けた定点測位では、測位分布は衛星配置に依存するが、今回のように自動車で市街地を走行 した場合には、周囲の建造物等による衛星電波の遮蔽が頻繁に発生し、測位に使用する衛星が頻繁に切り

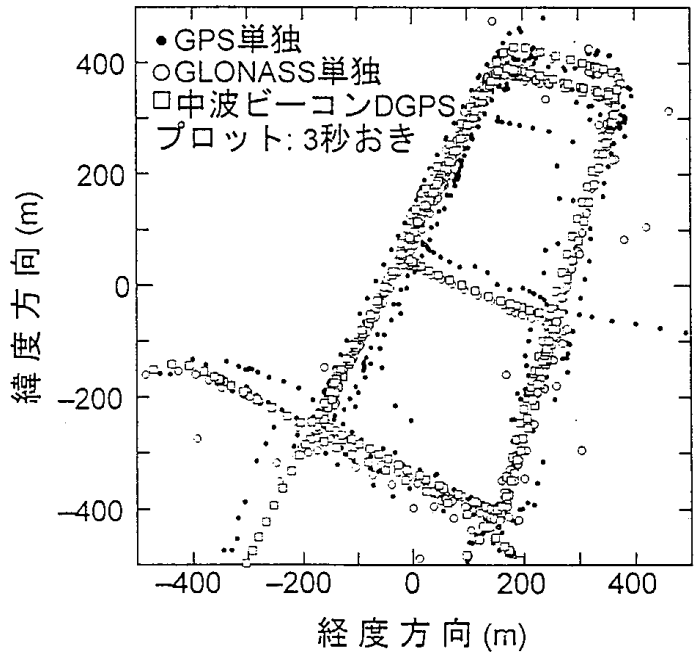

図 8 自動車における皇居前広場測位結果

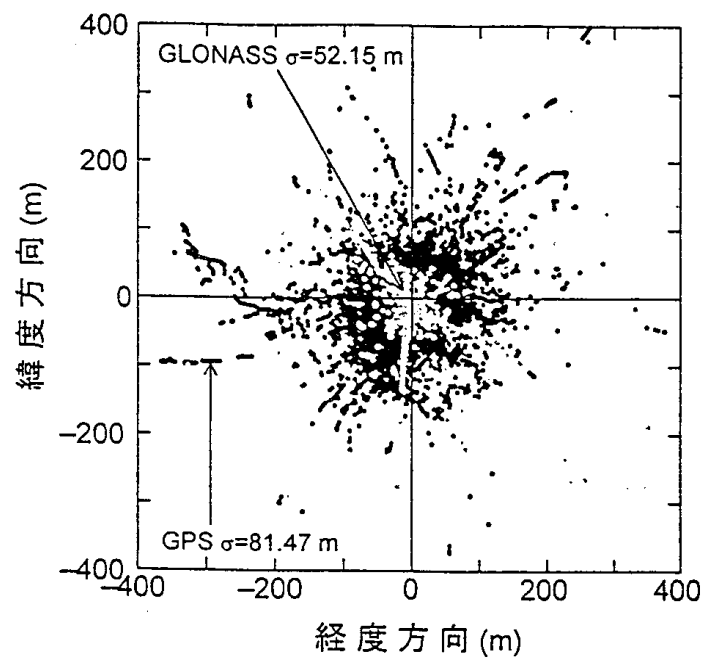

図 9 自動車における測位の精度評価 
表 5 自動車における測位時の衛星数の割合 [\%] (カッコ内測位回数)

\begin{tabular}{|c|c|c|c|c|c|c|c|}
\hline 使用衛星数 & GPS & \multicolumn{2}{|c|}{ GLONASS } & \multicolumn{2}{|c|}{ GPS+GLONASS } & \multicolumn{2}{|c|}{ 中波ビーコン DGPS } \\
\hline 3 衛星以下 & $19.1 \quad(6,096)$ & 88.8 & $(24,502)$ & 10.7 & $(1,726)$ & 10.6 & $(3,512)$ \\
\hline 4 衛星 & $10.0 \quad(3,184)$ & 7.9 & $(2,171)$ & 7.0 & $(1,133)$ & 15.0 & $(4,963)$ \\
\hline 5 衛星 & $14.5 \quad(4,643)$ & 3.1 & $(857)$ & 11.8 & $(1,899)$ & 22.3 & $(7,369)$ \\
\hline 6 衛星 & $\begin{array}{ll}17.7 \quad(5,640) \\
\end{array}$ & 0.2 & $(45)$ & 19.7 & $(3,184)$ & 25.5 & $(8,428)$ \\
\hline 7 衛星 & $(6,669)$ & 0.1 & (26) & 17.6 & $(2,847)$ & 18.6 & $(6,141)$ \\
\hline 8 衛星 & $(4,138)$ & 0.0 & $(0)$ & 12.5 & $(2,023)$ & 8.4 & $(2,766)$ \\
\hline 9 衛星 & $(1,568)$ & 0.0 & (0) & 9.1 & $(1,470)$ & 0.0 & (0) \\
\hline 10 衛星 & (15) & 0.0 & (0) & 4.1 & $(657)$ & 0.0 & (0) \\
\hline 11 衛星 & 0.0 & 0.0 & (0) & 3.0 & $(478)$ & 0.0 & (0) \\
\hline 12 衛星 & (0) & 0.0 & (0) & 2.6 & $(426)$ & 0.0 & (0) \\
\hline 13 衛星 & (0) & 0.0 & (0) & 1.7 & (274) & 0.0 & (0) \\
\hline 14 衛星 & $(0)$ & 0.0 & $(0)$ & 0.2 & $(40)$ & 0.0 & (0) \\
\hline 15 衛星以上 & $(0)$ & 0.0 & $(0)$ & 0.0 & $(0)$ & 0.0 & (0) \\
\hline 測 位 時 間 & 9.2 時間 & \multicolumn{2}{|c|}{7.7 時間 } & \multicolumn{2}{|c|}{4.5 時間 } & \multicolumn{2}{|c|}{9.2 時 間 } \\
\hline HDOP 值 $5 \geqq$ & $8.3 \% \quad(2,650)$ & $15.7 \%$ & $(4,331)$ & - & $(-)$ & $6.8 \%$ & $(2,247)$ \\
\hline HDOP 值 $10 \geqq$ & $2.6 \% \quad(846)$ & $10.4 \%$ & $(2,874)$ & - & $(-)$ & $3.4 \%$ & $(1,110)$ \\
\hline
\end{tabular}

替わるため、測位分布は予測できない。

表 5 にそのときの測位に使用した衛星数 の割合をまとめて示す。自動車で移動する ことによって周囲の環境が変化し、測位に 使用する衛星の切り替わりが頻繁に発生す る。また、高速道路の高架下を通過する場 合など、衛星を全く受信できないこともあ る。このため、HDOP值が 5 及び10より大
表 6 自動車における測位結果の差(中波ビーコンDGPS基潐)

\begin{tabular}{|c|c|c|c|}
\hline 項 & GPS & GLONASS & 中波ビーコン DGPS \\
\hline 測位時間 (1秒毎) & 9.2 時間 & 7.7 時間 & 9.2 時間 \\
\hline 測 位 泍 & $76.4 \%$ & $30.6 \%$ & $89.4 \%$ \\
\hline 測 位 回 数 & 28,389 & 4,996 & - \\
\hline $2 \mathrm{~d} r \mathrm{~m} \mathrm{~s}$ & $162.9 \mathrm{~m}$ & $104.3 \mathrm{~m}$ & - \\
\hline 高度方向標準偏差 & $105.5 \mathrm{~m}$ & $115.1 \mathrm{~m}$ & - \\
\hline
\end{tabular}

きくなる場合が定点測位時と比較して增加している。定点におけるGPS単独測位ではHDOP值が 5 より大 きくなることはなかったが、移動体走行中では $8.3 \%$ 、10より大きくなる場合が $2.6 \%$ 大ある。また、三次 元測位が不可能となる 3 衛星以下の割合も同様に増加しており、全ての測位システムで $10 \%$ を越えている ことが分かる。GPS単独測位は $19.1 \%$ に増加しており、GLONASS単独測位では $90 \%$ 近くが 3 衛星以下で あった。しかし、現状のGLONASS衛星の運用状態でも、GPSをGLONASSを併用することによって三次 元測位が可能な 4 衛星以上の割合がGPS単独測位の $80.9 \%$ か $89.3 \%$ に上昇することが分かる。 GLONASS衛星が24機運用されればさらなる測位率の向上が期待できる。

次に、表 6 に中波ビーコンDGPSを基準にした、水平方向放射状差と高度測位結果の差の標準偏差をまと めて示す。なお、GLONASS単独測位では測位率は $30.6 \%$ と低く、測位全体で 2 時間分程度の測位回数 ( 1 秒に 1 回測位)となっている。市街地を走行した場合、建造物等による衛星電波の遮蔽によって測位に使用 した衛星数が減少し、DOP值が増大する。また、複雑なマルチパス環境にあると考えられる。ここで、中 波ビーコンDGPSの測位結果を真の值として評価しているが、定点測位で差をとって評価した場合を例に とっても、真の值であると仮定した中波ビーコンDGPSの測位においても同様に䛊差が増大しているとい うことは容易に推測できる。実際に表 $2 ， 4 ， 6$ より、GPS単独測位に注目すると、定点測位結果で $2 \mathrm{drms}$ が49.42mであったものが、同じ結果を使用して中波ビーコンDGPSの同時刻の結果との差をとったものの $2 \mathrm{drms}$ は $52.47 \mathrm{~m}$ 、さらに自動車で走行中に差をとったものの $2 \mathrm{drms}$ は $162.94 \mathrm{~m}$ と值が増大していること が分かる。この誤差増大の影響はGPS単独測位にのみ現われるものではなく、当然真の值であると仮定し た中波ビーコンDGPSの結果にも現われているはずで、このため評価結果は表に示すような值になったと 考えられる。現状では運用されているGLONASS衛星の数が少ないため、GLONASS単独測位とGPS単独 測位において，測位精度に有意な差は見られなかった。 
表 7 船舶における受信衛星数の割合 [\%](カッコ内測位回数)

\begin{tabular}{|c||rr|rr|rr||rr||}
\hline 使用衛星数 & \multicolumn{2}{|c|}{ GPS } & \multicolumn{2}{|c|}{ GLONASS } & \multicolumn{1}{|c|}{ GPS+GLONASS } & 中波ビーコン DGPS \\
\hline \hline 3 衛星以下 & 0.0 & $(0)$ & 80.8 & $(34,524)$ & 0.0 & $(0)$ & 0.3 & $(83)$ \\
\hline 4 衛星 & 0.0 & $(0)$ & 17.7 & $(7,578)$ & 0.0 & $(0)$ & 4.5 & $(1,402)$ \\
\hline 5 衛星 & 0.0 & $(2)$ & 1.5 & $(650)$ & 0.0 & $(0)$ & 9.1 & $(2,825)$ \\
\hline 6 衛星 & 0.3 & $(114)$ & 0.0 & $(0)$ & 0.0 & $(0)$ & 13.6 & $(4,220)$ \\
\hline 7 衛星 & 9.3 & $(3,980)$ & 0.0 & $(0)$ & 0.1 & $(25)$ & 40.0 & $(12,416)$ \\
\hline 8 衛星 & 33.3 & $(14,233)$ & 0.0 & $(0)$ & 0.6 & $(249)$ & 26.3 & $(8,165)$ \\
\hline 9 衛星 & 37.6 & $(16,062)$ & 0.0 & $(0)$ & 6.7 & $(2,865)$ & 6.2 & $(1,919)$ \\
\hline 10 衛星 & 16.7 & $(7,129)$ & 0.0 & $(0)$ & 22.0 & $(9,425)$ & 0.0 & $(0)$ \\
\hline 11 衛星 & 2.9 & $(1,233)$ & 0.0 & $(0)$ & 29.9 & $(12,781)$ & 0.0 & $(0)$ \\
\hline 12 衛星 & 0.0 & $(1)$ & 0.0 & $(0)$ & 24.9 & $(10,637)$ & 0.0 & $(0)$ \\
\hline 13 衛星 & 0.0 & $(0)$ & 0.0 & $(0)$ & 12.6 & $(5,380)$ & 0.0 & $(0)$ \\
\hline 14 衛星 & 0.0 & $(0)$ & 0.0 & $(0)$ & 3.2 & $(1,364)$ & 0.0 & $(0)$ \\
\hline 15 衛星 & 0.0 & $(0)$ & 0.0 & $(0)$ & 0.1 & $(31)$ & 0.0 & $(0)$ \\
\hline 16 衛星以上 & 0.0 & $(0)$ & 0.0 & $(0)$ & 0.0 & $(0)$ & 0.0 & $(0)$ \\
\hline \hline 衛星受信時間 & 11.9 時 間 & 11.9 時間 & 11.9 時 間 & & 8.6 時 間 \\
\hline \hline HDOP 徝 $5 \geqq$ & - & $(-)$ & - & $(-)$ & $0.0 \%$ & $(0)$ & $0.2 \%$ & $(59)$ \\
\hline IIDOP 值 $10 \geqq$ & - & $(-)$ & - & $(-)$ & $0.0 \%$ & $(0)$ & $0.1 \%$ & $(34)$ \\
\hline
\end{tabular}

\section{2 船舶による測位笑験}

次に、東京商船大学の練習船汐路丸III世 (全長 $49.93 \mathrm{~m}$, 総トン数 $425 \mathrm{t}$ ) で、東京湾を南航中及び 神津島まで航行中に測位する実験を行った。図10 に東京湾を汐路丸で南行中に中波ビーコンDGPS を基準にして、同時刻の測位結果の差をとった GPS + GLONASS単独測位の水平方向分布を示 す。

次に、表 7 に汐路丸における受信衛星数の割合 をまとめて示す。GPS及びGLONASSのそれぞれ の単独測位は行っていないが、GPS+GLONASS単独測 位時の各受信衛星数の出力結果加求めた。海上に拈い ては上空が比較的開けて抢り、船舶の動摇によって低仰 角の衛星の受信状況が変化することが特徴である。同じ 移動体でも、都内を自動車で走行した場合の表 5 と比較 して測位に使用した衛星数は多く、GPS単独測位及び GPS+GLONASS単独測位では常時 5 衛星以上を测位 に使用していたことが分かる。しかし、中波ビーコン DGPSでは測位に使用している衛星が 3 機以下になる場 合や、HDOP值が 5 より大きくなる場合が発生してお り、船舶の動摇や船上構造物による衛星電波遮蔽の影響 が現れていることが分かる。しかし、この影響は船舶の 設計時からGPSもしくはGPS/GLONASSアンテナを最 適な位置に取り付けることにより改善できる。同表より、

GPS+GLONASS単独測位では常時 7 衛星以上使用して測位がなされており、GPSのSAが解除されれれ゙ DGPSに近い精度で測位できると考えられる。

また、表 8 にその $2 \mathrm{drms}$ と高度測位結果の差の標準偏差をまとめて示す。それぞれ $40 \mathrm{~m}$ と $20 \mathrm{~m}$ 前後であ
表 8 船舶における測位結果の差 (中波ビーコンDGPS基準)

\begin{tabular}{|l|c|c|}
\hline 項 目 & GPS+GLONASS & 中波ビーコン DGPS \\
\hline \hline 測位時間 (1 秒每) & 11.9 時間 & 8.6 時間 \\
\hline 測 位 率 & $99.6 \%$ & $99.7 \%$ \\
\hline 測 位 回 数 & 30,919 & - \\
\hline $2 \mathrm{~d} \mathrm{~m} \mathrm{~s}$ & $47.48 \mathrm{~m}$ & - \\
\hline 高度方向標淮偏差 & $25.68 \mathrm{~m}$ & - \\
\hline
\end{tabular}

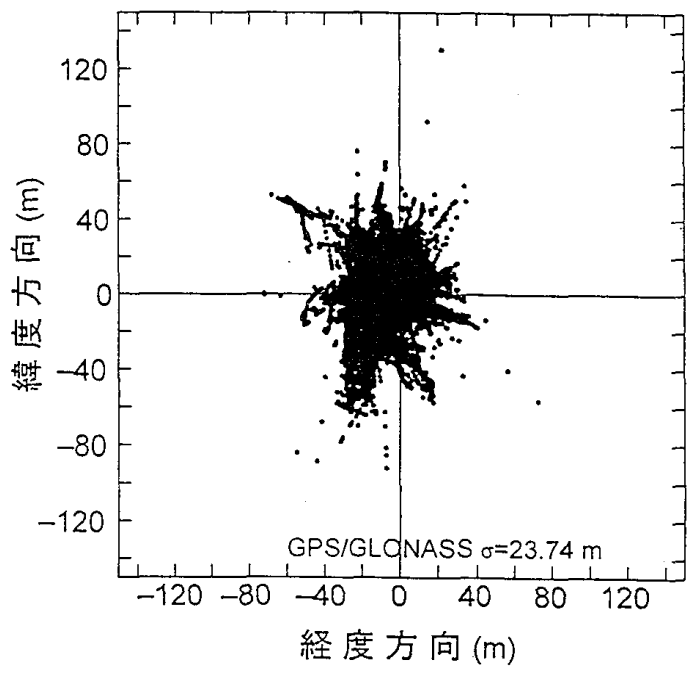

困10 船舶におうる測位の精度評価 
り、現状はこの程度であるといえる。

\section{5. まとめ}

今回、これまでにほとんど報告のないGLONASS単独測位及びGPS+GLONASS単独測位の移動体での 測位状況を把握するために、自動車及び船舶で移動中に測位を試みた。

市街地を走行する自動車における測位では、定点測位と比較して測位に使用できる衛星数が減少した。 GLONASS単独測位では測位率は $30.6 \%$ と低いが、GPSと併用することにより三次元測位が可能な 4 衛星 以上を測位に使用できる割合が $89.3 \%$ 以上と、GPS単独測位の $80.9 \%$ より $8.4 \%$ 高くなり有効である。この 值は、GLONASS衛星数が当初の計画に近づけば更に改善される。自動車における測位では、測位に使用 できる衛星数が重要であり、測位率を向上させるため及びDOP值を改善するためにGPSとGLONASSの 併用が望ましい。現状におけるGPS+GLONASS単独測位の精度は、HDOP值が 2 より小さい場合、標準 偏差で $20 \mathrm{~m}$ 前後であった。

海上を航行中の船舶における測位では、主に船舶の動摇による受信衛星の切り替わりが頻繁に発生する が、ほとんどが低仰角の衛星であるため測位への影響は少ないことが分かった。しかし、GPSとGLONASS を併用すれば、常時 7 機以上の衛星を測位に使用することができ、GPS+GLONASS単独測位の精度は 2 drmsで $40 \mathrm{~m}$ 、高度方向標準偏差で $20 \mathrm{~m}$ 前後であった。

将来GPSのSAも解除されると聞いているので、今後GLONASS衛星の打ち上げにより、測位精度の向上 が期待できる。

最後にGPS/GLONASS受信機Ashtech GG-24を貸与頂きましたDXアンテナ社、自動車を貸与頂きま した日本自動車連盟に謝意を表します。

\section{参 考 文 献}

（1）安田明生・浪江宏宗・岡村知則・新井貴之：「DGPS補正データのデータ放送による伝送」, 日本航海 学会誌NAVIGATION第128号，pp.48～54，1996年 6 月25日.

（2）安田明生・岡村知則・浪江宏宗・川村雅志：「中波ビーコンに重畳されたDGPS補正データ放送の受 信」，日本航海学会論文集第 95 号，pp.45〜 50，1996年 9 月 25 日.

(3) Akio YASUDA, Hiromune NAMIE, Naoto TANAKA, Takahiro YAMADA and Takuya TAKAHASHI, "DGPS Correction Data Broadcasting in Japan by MF Marine Radiobeacon and Evaluation of the Positioning Accuracy", Proceedings of the 9th International Technical Meeting of the satellite Division of the Institute of Navigation ION GPS-96 Part 1 of 2, pp.385-392, 17 Sep.1996.

（4）高橋卓也・安田明生・浪江宏宗：「DGPS測位における伝送誤りを含む補正データの有効な利用方法 の検討」, 平成 8 年度電子情報通信学会東京支部学生会第 2 回研究発表会講演論文集, p.20, 1997年 3 月 6 日.

（5）鈴木智明・安田明生・浪江宏宗・毛 碩峰：「中波ビーユン電波に重畳された補正データを用いた DGPS連続測位」，平成 8 年度電子情報通信学会東京支部学生会第 2 回研究発表会講演論文集, p. 21 , 1997年 3 月 6 日.

(6) Akio YASUDA, Naoto TANAKA and Hiromune NAMIE, "DGPS Correction Data Dissemination in Japan and Evaluation of the Positioning Accuracy", GNSS 98-ACTES Proceedings-Tome 2 VII-P-02, pp.1-6, 20 Oct. 1998.

（7）安田明生・浪江宏宗・田中直人・李 大軍・禁 春明：「日本にお沙るDGPS補正データ放送の現状 と測位精度評価」，日本航海学会誌NAVIGATION第138号，pp.70～72，1998年12月25日。

\section{質 疑 応 答}

惟村和宣 (運輸省 電子航法研究所)：GLONASSが 4 衛星受信できていても誤差の增大が見られるが、こ のときのDOPはどうなっていたのか？ 
浪江宏宗：本文中の図 4 にも示しましたが、測位にGLONASS衛星を 4 機使用していてもHDOP值が40近 くにまで増加する場合があり、この時間帯では緯度方向測位結果に $30 \mathrm{~m}$ 以上にわたるジャンプが発生し ていました。このことから、測位に使用している衛星数と共に、DOP值にも十分注意する必要があると 考えます。 